\title{
Resolving confusions about jarrah dieback - don't forget the plants
}

\author{
E. M. Davison
}

Received: 23 April 2014 / Accepted: 10 June 2014 /Published online: 19 June 2014

(C) Australasian Plant Pathology Society Inc. 2014

\begin{abstract}
The name jarrah dieback has been used for two different disorders, leading to considerable confusion. It was coined in the 1940s to describe the sudden death of groups of jarrah (Eucalyptus marginata) trees in south western Western Australia, which occurred on poorly drained sites, following exceptionally heavy rainfall. In the 1960s these sites were shown to be infested by Phytophthora cinnamomi and jarrah deaths were attributed to it, even though it was only isolated from $5 \%$ of sampled trees. Also the definition of jarrah dieback was expanded to include deaths of many other plants on infested sites, from which P. cinnamomi was more readily isolated. Jarrah trees die from severe water deficiency, indicating problems with water conduction through roots. Xylem vessel diameters vary along roots, being narrow at the root collar, while distally they are larger, providing water storage. Jarrah transpires vigorously during summer, accessing water at depth on sites with deep soil, but being more dependent on internally stored water when root systems are shallower. Following waterlogging, sapwood vessels become blocked with tyloses, reducing both conductivity and potential water storage; such trees may have insufficient water reserves for summer survival. In jarrah $P$. cinnamomi is unlikely to cause water deficiency because sapwood invasion is rapidly contained in healthy roots. Recent investigations into P. cinnamomi invasion and host responses in other plants show that it can potentially cause a vascular wilt in Banksia spp. and chronic, symptomless infections in herbaceous plants. Susceptibility to waterlogging damage, and/or mortality resulting from infection by P. cinnamomi can only be clarified by detailed knowledge of the hosts and their
\end{abstract}

Electronic supplementary material The online version of this article (doi:10.1007/s13313-014-0302-y) contains supplementary material, which is available to authorized users.

E. M. Davison $(\bowtie)$

Department of Environment and Agriculture, Curtin University, GPO Box U1987, Perth, WA 6845, Australia

e-mail: E.Davison@curtin.edu.au vulnerabilities. This is essential for making diagnoses, devising management strategies, and avoiding the confusions of the past.

Keywords Banksia spp · Eucalyptus marginata . Phytophthora cinnamomi $\cdot$ Phytophthora dieback $\cdot$ Roots . Tension wood · Tree death · Tyloses · Waterlogging · Water storage $\cdot$ Xylem vessels

\section{Introduction}

The plant disease triangle is a fundamental concept that underlies the understanding and management of plant disease. It presupposes knowledge of the host, the pathogen and the environment, how these interact, and how they can be modified to minimise the risk of severe disease developing. Agricultural crops are well known: plant pathologists have access to an extensive literature on their structure, physiology, nutritional requirements and genetics, all of which feed into practical control measures. Native plants in natural ecosystems however are a different proposition because so little is known about them. How can we understand a diseased plant without a detailed knowledge of a healthy one? This was the situation confronting me when I arrived in Perth, to work on jarrah dieback, a major problem in the jarrah forest in the southwest of Western Australia (WA). Consequently I have spent time investigating jarrah (Eucalyptus marginata) in addition to working with the introduced soil-borne pathogen Phytophthora cinnamomi. This paper outlines this journey, and the conclusions reached.

\section{Jarrah dieback, background}

Jarrah dieback was a forester's worst nightmare. Groups of jarrah trees of all ages and size classes died, often very 
suddenly, in the northern jarrah forest, during the wet decades from the mid-1940s to mid-1960s [Supplementary data 1]; these sites were known as dieback sites. As jarrah was the most important timber exported from Australia at that time, these deaths were investigated by officers from both the Commonwealth Forestry and Timber Bureau and the WA Forests Department.

Affected sites were of poor site quality with low stocking, even though they had a large quantity of merchantable timber. The sites were in specific topographical positions such as at the break of slope, in gully heads, upper sections of drainage lines and on slight saddles in ridges. Most had been recently logged for the first time; and had a tendency to become waterlogged in winter (Waring 1950; Hamilton 1951, Wallace and Hatch 1953). Further observations by Loneragan (1961) confirmed the association between jarrah deaths and winter flooding in particularly wet years such as 1955. Jarrah was not the only tree that died, the common mid-storey trees Banksia grandis and Allocasuarina fraseriana also died, but marri (Corymbia calophylla) that often grows in association with jarrah, was not affected.

There were several investigations into the cause of these deaths. The possibility that jarrah deaths were caused by a pathogen were investigated by Harding (1949) (with associated anatomical studies being conducted at CSIRO's Division of Forest Products in Melbourne) and Stahl and Greaves (1959). Neither investigation found evidence of consistent fungal lesions; however both investigations reported that there were tyloses and gummosis, particularly in the root sapwood of affected jarrah trees. As WA soils are very infertile, Wallace and Hatch (1953) conducted an extensive investigation into whether these tree deaths were the result of nutritional deficiency, but they concluded that this was unlikely.

It was against this background that Podger took up a research officer position to investigate these deaths in 1959. After some time he started to determine whether a Phytophthora might be a possible cause of the death of jarrah trees, and many associated mid-storey and understorey plants. Initial attempts to isolate Phytophthora spp. from field samples of jarrah roots and soil were unsuccessful, but $P$. cinnamomi was eventually isolated in 1964 from forest soil used in glasshouse experiments (Podger et al. 1965). Podger spent the next two years testing the hypothesis that P. cinnamomi caused jarrah dieback (Podger 1968; 1972). He showed that it was consistently isolated from dieback sites but not from unaffected forest. It was isolated from 55 species of native plants including jarrah, and it was shown to be pathogenic to seedlings of jarrah and other native species. He also inoculated three unaffected, low quality forest sites with cultures of $P$. cinnamomi and soil from a dieback site. Dieback symptoms including death of understorey species appeared within 16 months, and after
6 years one jarrah tree had died. P. cinnamomi was recovered from both soil samples and plant roots. Podger concluded that there is 'little doubt that $P$. cinnamomi is the cause of ... jarrah dieback ...', and specifically in relation to jarrah 'it seems unlikely that there will be sufficient resistance to prevent serious damage wherever P. cinnamomi establishes' (Podger 1972).

It was soon realised that jarrah did not necessarily die on sites infested by P. cinnamomi. B. grandis, and understorey species such as Xanthorrhoea preissii and X. gracilis were more reliable indicators of site infestation (Havel 1979; Brandis 1983). Growth measurements of six trees however showed that jarrah grew at less than $15 \%$ of the rate of ten trees of similar size in nearby healthy forest (Podger 1972) so foresters believed that once a site became infested, growth rate would decrease, sites would be unproductive, and the jarrah trees would eventually die. Consequently research centred on learning more about $P$. cinnamomi under WA conditions, mapping its distribution, minimising spread, and looking for field tolerant timber species for replanting (Wallace 1969; Podger and Batini 1971; Batini and Hopkins 1972; Batini 1973; Christensen 1975; Shea 1975).

There was, however, a problem with the interpretation that $P$. cinnamomi killed jarrah trees that was not widely recognised at the time. Although P. cinnamomi had been isolated from jarrah, it had only been isolated from $5 \%$ of the sampled trees (Table 1), and this low recovery did not satisfy the first of Koch's postulates. It is unfortunate that Podger $(1968$; 1972) did not draw attention to this low isolation frequency at the time. It had been isolated more frequently from $B$. grandis (29 \%) and from soil samples (23\%). This did not mean that $P$. cinnamomi was unimportant, but what was needed was an explanation about how the jarrah trees had died and why the isolation frequency from jarrah was so low. These have been the main aims of my investigations into jarrah.

Table 1 Isolation frequency of Phytophthora cinnamomi from various hosts in the jarrah forest of Western Australia. Isolation methods: direct plating onto 3P or $\mathrm{P}_{10} \mathrm{VP}$ agar or by lupin baiting (Erwin \& Ribeiro 1996). Data from the isolation books, May 1965 to December 1968 , viewed with permission by CSIRO in February 1980, and published with permission from CSIRO in 2011. From Davison (2011) with permission from the New Zealand Journal of Forestry Science

\begin{tabular}{lll}
\hline Host & Sample size & Isolation frequency (\%) \\
\hline $\begin{array}{l}\text { Eucalyptus marginata } \\
\text { (jarrah) }\end{array}$ & 100 & 5 \\
Banksia grandis & 121 & 29 \\
Other plants & 546 & 19 \\
Soil samples & 1,163 & 23 \\
\hline
\end{tabular}




\section{The host, jarrah}

Jarrah growth and death

I was curious about when the growth rate of jarrah decreased. Was it immediately after the trees became infected (at the margin of a dieback site), or many years later after understorey plants had died and the site conditions had changed substantially? As no appropriate forest inventory data was available, a growth trial was established at Churchmans block $\left(32^{\circ} 11^{\prime} \mathrm{S} 116^{\circ} 4^{\prime} \mathrm{E}\right)$ in 1980 to answer this question (Davison and Tay 1988). There were three groups of trees: in the dieback area where P. cinnamomi had killed mid- and under-storey vegetation, in the adjacent uninfested (healthy) area, and at the margin of the dieback and uninfested (intermediate) area. One tree from each area was selected and then matched on underbark diameter with a tree from the other two areas, with twelve groups of similar size trees being selected. They were fitted with dendrometer bands at $1.3 \mathrm{~m}$ (Liming 1957), and measured every 2 weeks. Within a short time it was apparent that the jarrah trees in the dieback and intermediate areas were growing faster than trees in the healthy area, and this continued for 5 years. An additional growth trial was established at Karnet block $\left(32^{\circ} 24^{\prime} \mathrm{S} 116^{\circ} 4^{\prime}\right.$ E) to check these measurements, but on this site trees in the different areas of the site all grew at the same rate. Similar observations have been made by Crombie and Tippett (1990). Thus it appeared that jarrah trees did not necessarily grow significantly slower on dieback sites, as reported by Podger (1972).

Five jarrah trees died during the course of these growth trials. All of the deaths were of trees on the dieback or intermediate areas of the sites, all died in a similar way, and all died during late spring, summer or autumn. Two of these deaths are shown in Fig. 1 (Davison and Tay 1995a). The trees showed sudden and sustained stem shrinkage at $1.3 \mathrm{~m}$ for several weeks or months before the crown died, with the foliage changing in colour from green to brown within a 4 week period. Crombie and Tippett (1990) have made similar observations. All of these observations of stem shrinkage, together with measurements of stomatal conductance and xylem pressure potential (Shea et al. 1982; Crombie and Tippett 1990) indicated that the trees died from severe water stress. Hydraulic failure must be originating somewhere in the root system because it was detected by the dendrometer bands at $1.3 \mathrm{~m}$, before symptoms were apparent in the crown. The first place to check for dysfunction was obviously the root sapwood.

Conductivity of jarrah roots

One way to study the conductivity of sapwood is by gas flow under positive pressure (Zimmermann and Jeje 1981). If a piece of stem or root is cut shorter than the average length of its xylem vessels some of these vessels will be open at both ends. If gas is blown gently through the sapwood, bubbles of gas will emerge at the other end which can be collected and measured. Most of the xylem vessels in jarrah roots are 40 to $50 \mathrm{~cm}$ long, with the remainder about $1 \mathrm{~m}$ in length (Davison and Tay 1995a), so that in root segments that are only $20 \mathrm{~cm}$ long most of the vessels will be open at both ends. Fig. 2 shows the relative conductivity of root sapwood of six roots from six of the measured and matched trees from the Churchmans and Karnet blocks. Flow rate was very slow close to the base of the tree, and up to 10 times faster $2 \mathrm{~m}$ from the bole. There was no difference in relative conductivity/flow rate between the roots from trees of different dieback status, but there was a difference between the two sites. Anatomical observations showed that the difference in flow rate was associated with an increase in the maximum xylem vessel diameter along the root (Fig. 3), not a difference in the number of xylem vessels along the root. As flow rate through capillaries is proportional to the fourth power of the radius (Zimmermann 1983) this difference in diameter accounts for the difference in conductivity.

Tension wood at the root collar, hydraulic bottleneck, and water storage

Differences in conductivity along roots resulting from differences in conduit diameter and/or density have been observed in other trees (Pate et al. 1995; McElrone et al. 2004; Christensen-Dalsgaard et al. 2007a). Trees produce tension wood at the base of the stem and proximal end of large roots in response to stresses caused by wind (Stokes and Mattheck 1996; Christensen-Dalsgaard et al. 2007b). Tension wood is very dense and strong, because it has a high proportion of fibres (Fig. 3a) providing increased mechanical stability and resistance to windthrow. However this high proportion of fibres results in narrow xylem vessels, and this hydraulic bottleneck means that damage to the sapwood at this point, whether by pests, pathogens or mechanical means, will have a far greater effect on tree function than a similar amount of damage further from the root collar.

Wide xylem vessels imply efficient conduction; however sap flow from these roots will be restricted by the hydraulic bottleneck at the root collar. The wide xylem vessels distal to the root collar contain a large volume of water (Dodd et al. 1984), constituting one of the water reservoirs within the tree.

\section{The Mediterranean environment}

The southwest of WA has a Mediterranean climate, with warm wet winters and hot dry summers. Even though the 
Fig. 1 Comparison of girth changes at $1.3 \mathrm{~m}$, leaf production and crown death of matched pairs of Eucalyptus marginata trees. Key: girth of tree in dieback or intermediate area; - girth of matched tree in healthy area;" young leaves present in the crown: $\rightarrow$ death of foliage. A: Karnet block, trees K40 (intermediate area) and K47 healthy area. B: Churchmans block, trees Ch 17 (intermediate area) and Ch 69 healthy area. Modified from Davison and Tay (1995), reproduced with permission from New Phytologist
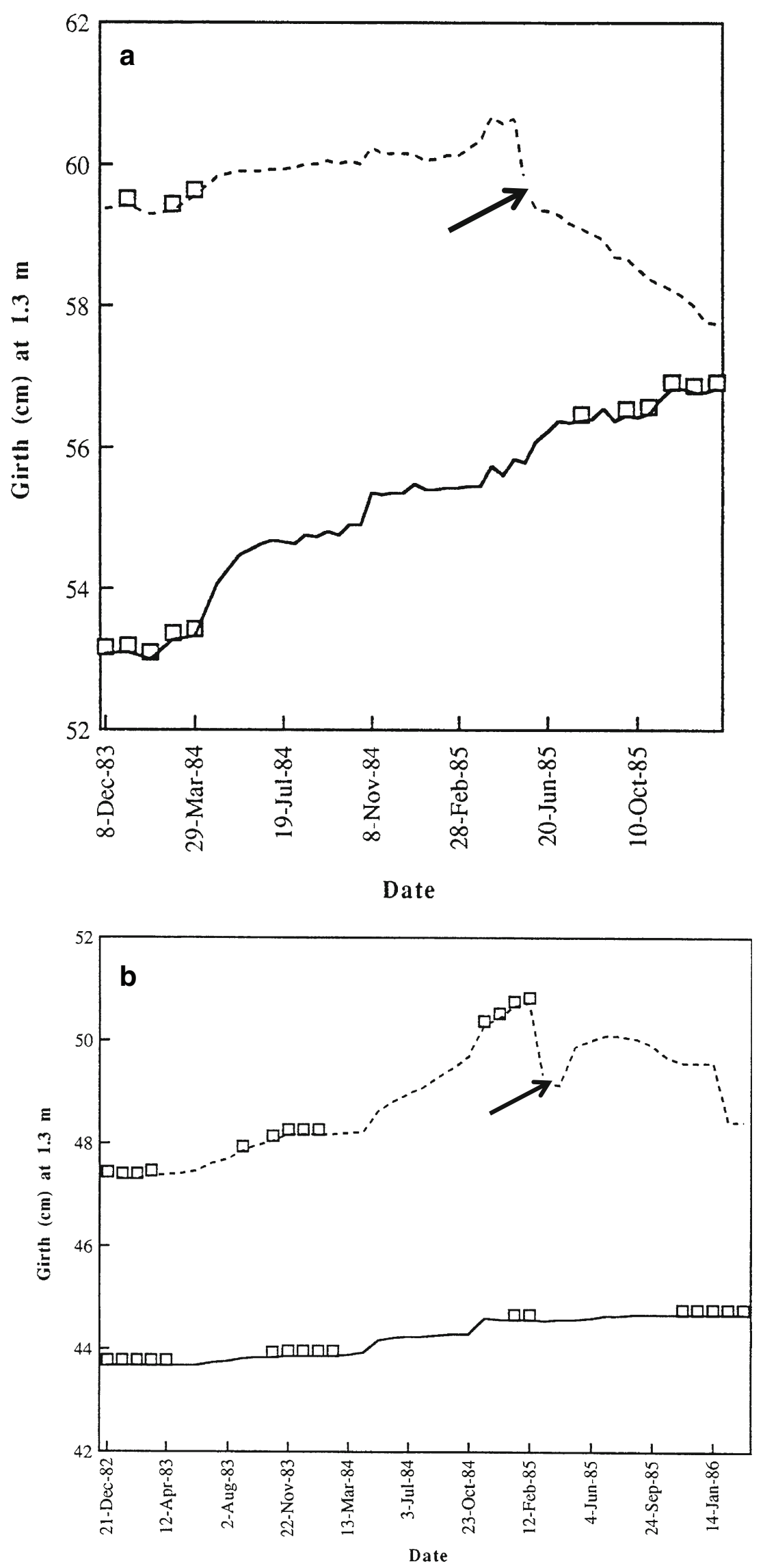
Fig. 2 Gas flow

$\left(\mathrm{cm}^{3} \mathrm{~mm}^{-2} \mathrm{~min}^{-1}\right)$ through the sapwood of $20 \mathrm{~cm}$-long segments from horizontal roots of Eucalyptus marginata trees.

There were two roots from three matched trees from the dieback, intermediate and healthy areas of both the Churchmans and Karnet blocks. Key: $\square$ dieback area, $\Delta$ intermediate area, 0 healthy area. From Davison and Tay (1995), reproduced with permission from New Phytologist

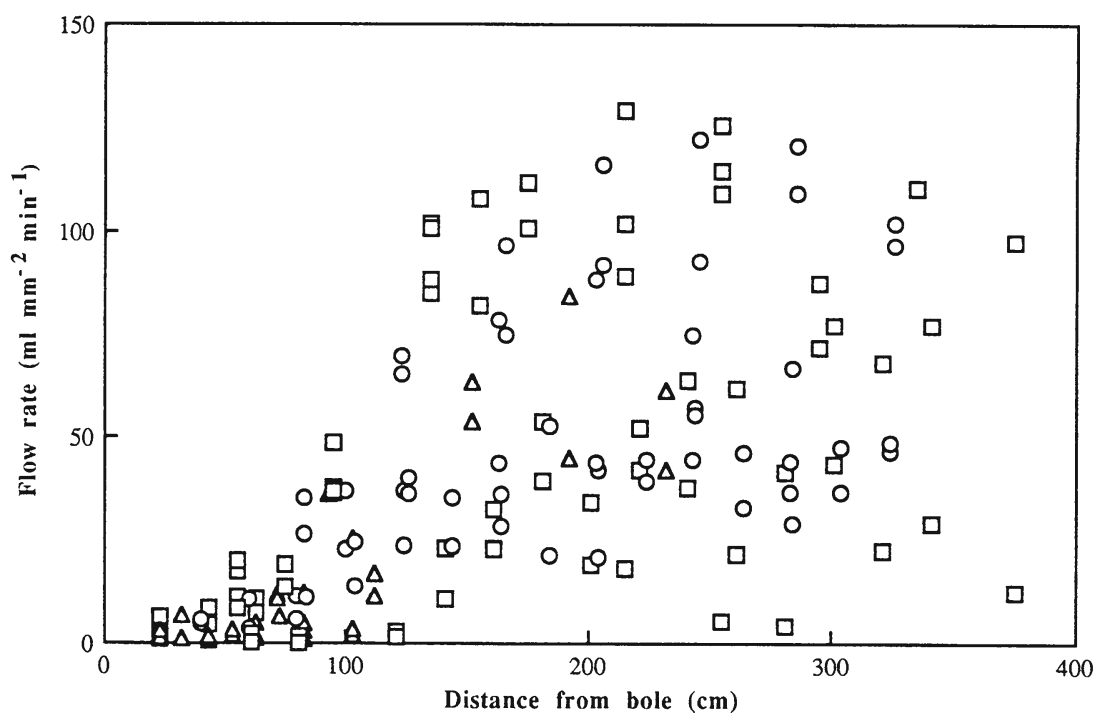

rainfall is seasonal, jarrah trees grow all the year round (Fig. 4; Abbott and Loneragan 1986; Davison and Tay 1989). Cambial activity is opportunistic, occurring when the surface soil is moist and there is adequate soil aeration, which is mainly during autumn, winter and spring. During late spring, summer and early autumn, when the surface soil is dry, the trees produce new leaves, and in some years also produce flower buds. Jarrah phenology, together with vigorous transpiration during summer (Doley 1967; Silberstein et al. 2001; Poot and Veneklaas 2013) indicates that these trees must have access to water throughout the year.

Jarrah has a very large root system with extensive lateral roots in the surface $1 \mathrm{~m}$ of soil and deep, vertical roots that are believed to extend to depths of up to $40 \mathrm{~m}$ into the soil profile (Kimber 1974; Dell et al. 1983). During summer, jarrah is believed to access water from moist soil above deep water tables, clay horizons at depth, or from loosely bound

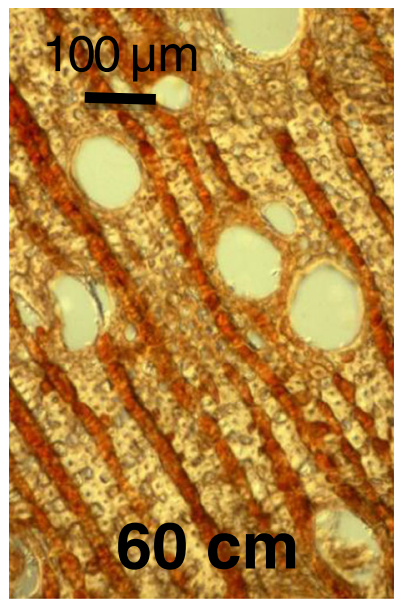

a

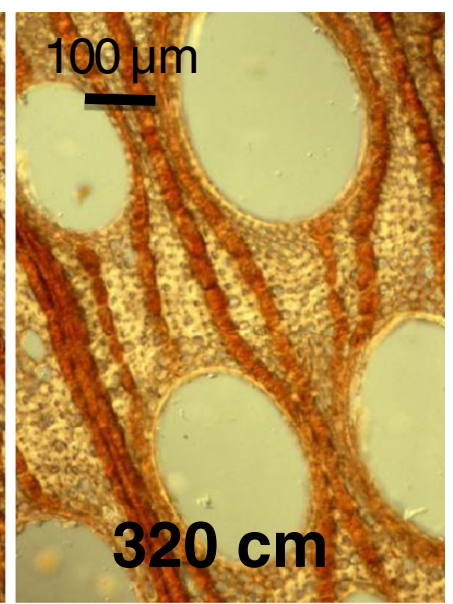

b
Fig. 3 Transverse section through the sapwood of the Eucalyptus marginata root 30A from Karnet block at $60 \mathrm{~cm}$ (a) and $320 \mathrm{~cm}(\mathbf{b})$ from the root collar water in deep root channels (Carbon et al. 1981; Crombie et al. 1988), although attempts to confirm this have been inconclusive (Farrington et al. 1996). As mentioned above, jarrah also stores water in the xylem vessels in root sapwood which will be released when the water potential is low enough for cavitation to occur. Additional water will be stored in parenchyma cells with elastic walls, and in embolised wood cells and intercellular spaces (Tyree and Yang 1990).

\section{Waterlogging damage}

Jarrah grows on a wide range of sites, but it grows best on deep, well drained lateritic soils (Stoate and Helms 1938; Abbott and Loneragan 1986). Seedlings do not tolerate

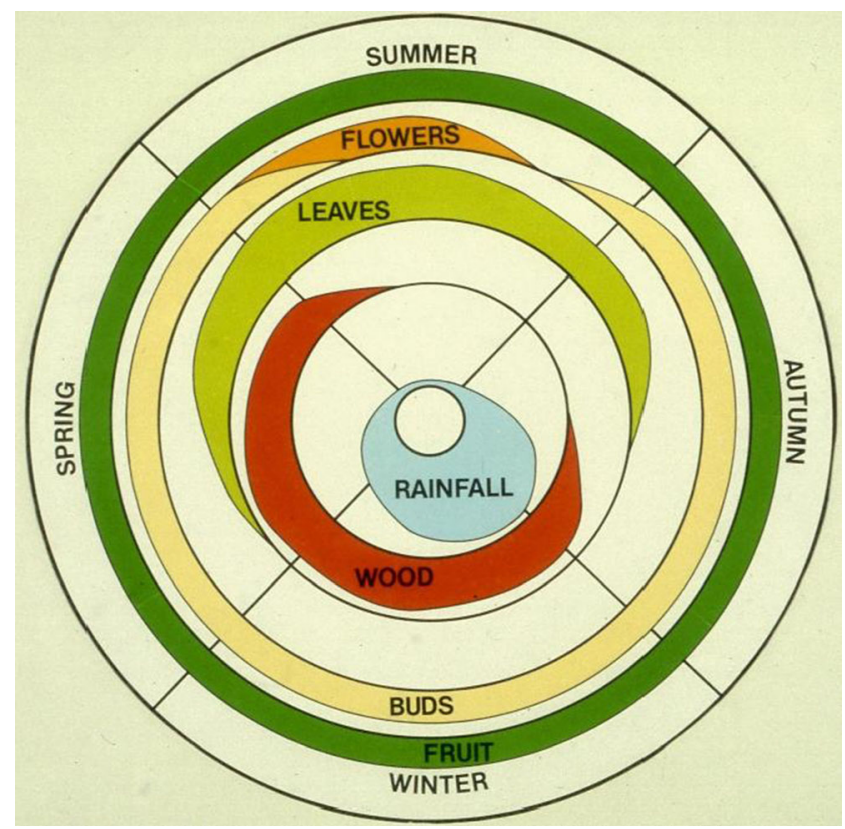

Fig. 4 Jarrah phenology, Churchmans block dendrometer band trial 
flooded soil (Podger 1967) and its distribution is determined by seasonal waterlogging (Fordyce et al. 2007). Low quality sites include those with a seasonally perched watertable, resulting from duplex soils or rock close to the soil surface. Examination of the root systems of windthrown trees on these low quality sites shows that vertical roots are not numerous and those that do occur are not well developed; they are often short and fanged (Fig. 5), indicating that they have been repeatedly pruned off by seasonal waterlogging.

Waterlogging has profound anatomical and physiological effects on jarrah. When seedlings are waterlogged the xylem vessels in the tap root rapidly cavitate and become occluded with tyloses (Fig. 6), with the proportion of tylosed vessels being proportional to the duration of flooding (Davison and Tay 1985). As tylosed vessels contain air not water they are no longer able to conduct water (Zimmermann 1983). Most tree seedlings close their stomata when they are waterlogged, but jarrah does not and continues to transpire (Davison and Tay 1985). Consequently during summer, when transpiration rates are high, seedlings wilt and die (Fig. 7).

Tylosed sapwood also develops in the roots of jarrah trees that have been waterlogged. For example this was the only symptom seen in dead jarrah trees that had been waterlogged 11 months earlier, following exceptionally heavy rainfall and increased discharge of water into the site from nearby roadworks (Davison 1997). In vertical roots $75 \%$ of the sapwood vessels were tylosed, while $25 \%$ were tylosed in horizontal roots. The greatest effect of this sudden decrease in the proportion of functional xylem vessels would have been to suddenly reduce the internal water storage of root sapwood, leading to drought stress and foliage death the following summer.

\section{Vulnerability of jarrah}

The main vulnerability of jarrah is its requirement for rapid transpiration throughout the year, especially during the hot,

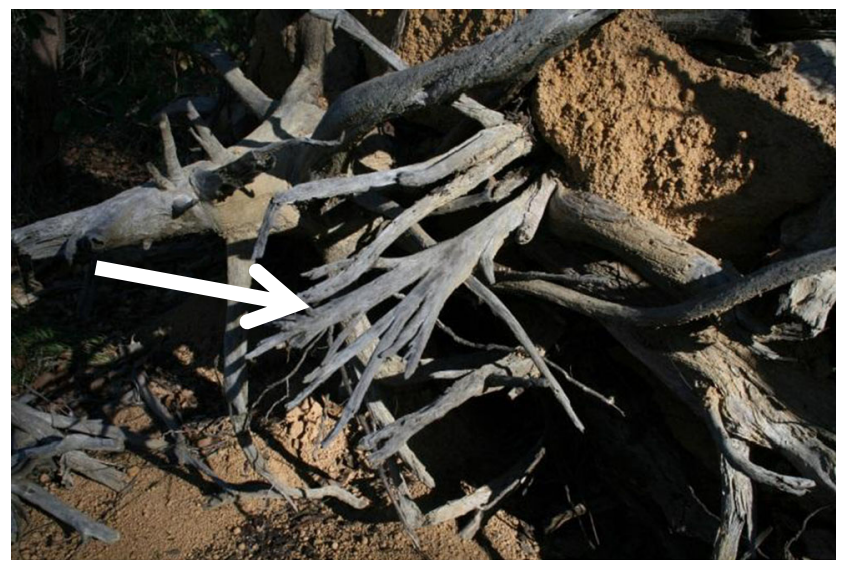

Fig. 5 Fanged vertical roots from a site with seasonal perched water tables dry summer, and it is at this time of year when deaths are most likely to occur. The sites where the trees are most at risk are those where the soil profile does not allow trees to develop an extensive deep, vertical root system, so that summer survival is much more dependent on internally stored water. Quite apart from the size of its root system, the amount of this water store will be affected by external factors such as rainfall and by internal factors such as xylem vessel diameter, and the proportion of tylosed vessels. Conduction of water from the roots to the stem and foliage will also be affected by any damage to tension wood at the base of the tree.

\section{The pathogen, Phytophthora cinnamomi}

The death of jarrah trees on dieback sites results from severe water deficits that lead to hydraulic failure (Fig. 1; Shea et al. 1982; Crombie and Tippett 1990; Davison and Tay 1995a). So if this symptom is caused by P. cinnamomi this pathogen must be able to extensively invade the sapwood and reduce conductivity.

Tippett et al. (1983) have shown that P. cinnamomi causes necrotic lesions in the phloem (inner bark), but not the sapwood of wound inoculated stems and roots of jarrah trees. However P. cinnamomi is a hemibiotroph, it causes an inapparent infection axially and tangentially in the phloem and radially into the sapwood. This colonisation can be demonstrated by plating (Davison et al. 1994; Hüberli et al. 2002). Fig. 8a shows that 1 week after wound inoculation of jarrah stems and roots, it can be recovered from the sapwood up to $5 \mathrm{~mm}$ internal to the cambium. Rapid responses by the host mean that the symptomless infection is confined to this narrow band of sapwood, even after several months. There is no indication of disrupted conduction in the sapwood immediately internal to the inoculation point. The only possible way that $P$. cinnamomi could damage jarrah roots sufficiently to cause severe water deficits to develop, is if infection occurs simultaneously in the tension wood of all major roots. This has not been observed in many of the investigations into the deaths of groups of jarrah trees (Harding 1949; Stahl and Greaves 1959; Podger et al. 1965; Podger 1968; Shea et al. 1982; Davison 1997), although infection at the root collar does occur occasionally (Dell and Wallace 1981; Shearer et al. 1981; Crombie and Tippett, 1990; Hardy et al. 1996).

Banksia spp. (Proteaceae) behave differently from jarrah (Myrtaceae). A hemibiotrophic infection is also formed when they are wound inoculated, but the symptomless colonisation of the sapwood is much more extensive both radially and axially than in jarrah (Fig. 8b; Smith et al. 1997; Davison 2011; Davison et al. 2014). Hyphae are present in both the ray cells and xylem vessels and if there 
Fig. 6 Xylem vessels in the tap-root of four-month old $\mathrm{Eu}$ calyptus marginata 3 to $4 \mathrm{~cm}$ below the cotyledonary node. (a) unflooded control; (b) flooded for 8 days. From Davison and Tay (1985) reproduced with permission from New Phytologist

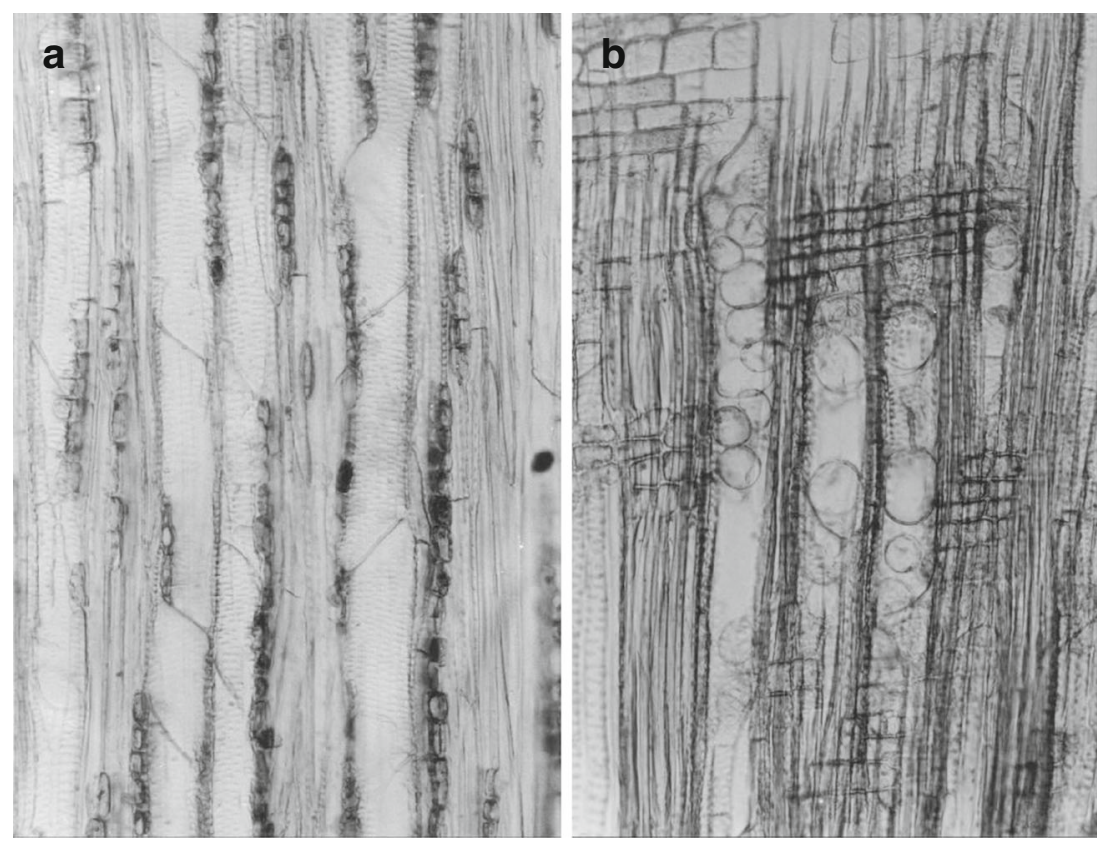

is a host response to infection it is too little, too late. Symptoms of banksia death on sites infested with $P$. cinnamomi are symptoms of wilting. Extensive colonisation of the sapwood following wound inoculation may indicate that this is the early stage of a vascular wilt.

\section{Discussion}

\section{P. cinnamomi, waterlogging, and the death of jarrah trees}

Knowledge of the vulnerabilities of jarrah trees, observations made by the earliest investigators of jarrah dieback, the association of tree deaths with exceptionally heavy rainfall [Supplementary data 1], together with results from more recent experimentation and observations indicates that the original problem called jarrah dieback resulted from waterlogging. Tree deaths were on sites where waterlogging had been observed (Waring 1950; Hamilton 1951; Loneragan
1961; Davison 1997), there were large numbers of tylosed xylem vessels in the root sapwood (Harding 1949; Stahl and Greaves 1959; Davison 1997) and there were no symptoms of consistent fungal lesions or insect damage (Harding 1949; Stahl and Greaves 1959; Podger et al. 1965; Davison 1997). Only one other investigation into tree deaths mentions tyloses, which in this instance were associated with P. cinnamomi lesions (Dell and Wallace 1981). Trees on sites where seasonal perched water tables occur have shallow root systems, so that they have less access to water stored in the soil profile for survival over summer than trees growing on well drained sites, and are more dependent on internally stored water. As tylosed sapwood, resulting from waterlogging damage will reduce both sapwood conductivity and the volume of stored water there is the potential for trees to develop very severe water deficits during summer, leading to hydraulic failure and death. Thus the mechanism for these deaths is that trees have insufficient water reserves to survive the hot, dry summer.
Fig. 7 The effect of water logging three-month-old Eucalyptus marginata for 3, 6 and 9 days in the summer. (a) unflooded controls; (b) flooded 3 days, drained 7 days; (c) flooded 6 days, drained 4 days; (d) flooded 9 days, drained 1 day. Modified from Davison and Tay (1985) with permission from New Phytologist

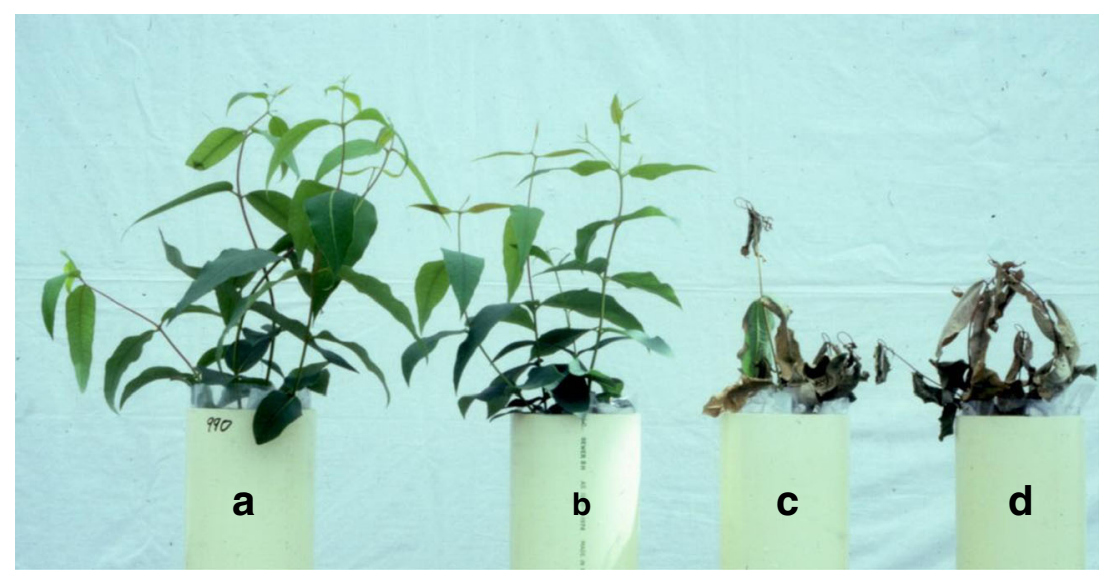


Fig. 8 Recovery of

Phytophthora cinnamomi after

1 week from the bark and

sapwood of (a) wound

inoculated stems and roots of

Eucalyptus marginata trees

(redrawn from Davison et al.

1994) and (b) wound

inoculated, excised stems of six

Banksia spp. (redrawn from

Davison et al. 2014)

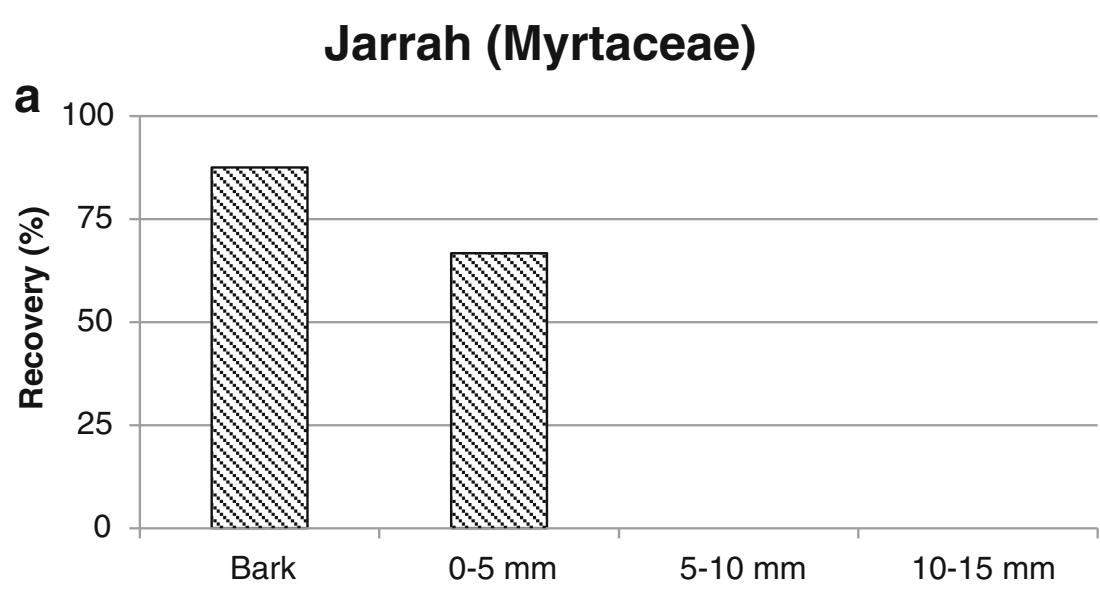

Distance invaded into sapwood at inoculation point

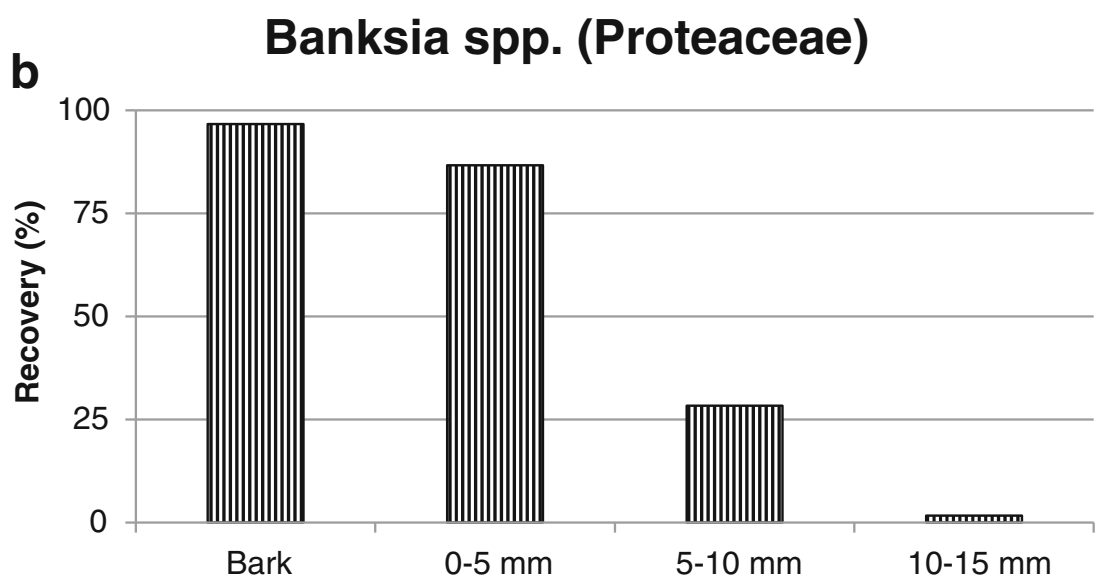

Distance invaded into spawood at inoculation point
Confusion has arisen following the isolation of P. cinnamomi from sites where jarrah trees had died. This confusion is firstly because Podger $(1968 ; 1972)$ expanded the definition of jarrah dieback to include the death of many mid- and under-storey species that also died on infested sites, and secondly, because he did not report the very low isolation frequency of $P$. cinnamomi from jarrah trees (Table 1, Davison 2011). Podger (1968), however, isolated P. cinnamomi from most of the sites where jarrah trees had died (although he mentions one site where jarrah had died but $B$. grandis was still alive). As the fine roots of jarrah were sparse and often rotted (Podger et al. 1965), Zentmyer (1968) proposed that $P$. cinnamomi caused a fine root necrosis which led to tree death. This explanation was widely accepted because fine root necrosis had been used to account for death or symptoms of decline in other trees, e.g. avocados (Wager 1942; Zentmyer and Thorn 1967) and pines (Campbell 1949; Newhook 1959). However, attempts to demonstrate extensive fine root necrosis in jarrah have been unsuccessful, although recovery could be increased by summer irrigation (Shea et al. 1980; Shea and Dell 1981).
There have been many subsequent attempts to explain jarrah deaths in terms of infection by P. cinnamomi, however, there is little repeatability between different investigations. Lesions on the roots of live trees are very infrequent (Shearer and Tippett 1989; Davison and Tay 1995b), and are readily contained by the host (Tippett et al. 1983; Tippett and Hill 1984; Tippett et al. 1985; Davison et al. 1994), so that large spreading lesions found in the sapwood at the root collar (Dell and Wallace 1981; Shearer et al. 1981; Hardy et al. 1996), or on vertical roots (Shea et al. 1982) are more likely to be the consequence of rapid colonisation of a dying tree, rather than the cause of death.

Death of mid-storey and under-storey plants

The greatest contribution made by Podger was to draw attention to the role of $P$. cinnamomi in the death of midand under-storey plants such as Banksia spp. (Table 1), in an area of great botanical diversity (Cahill et al. 2008; Shearer et al. 2009). It still needs to be elucidated whether it causes a vascular wilt in Banksia spp. and whether it is able to 
rapidly colonise the sapwood of other woody Proteaceae, such as Lambertia spp. and Persoonia spp,. in a similar way. This will be a fruitful area for future research.

In WA the name jarrah dieback sensu Podger has been changed to Phytophthora dieback (Department of Conservation and Land Management 2003) to better reflect widespread concern about deaths associated with site infestation, in areas outside the jarrah forest.

\section{The mortality rate of jarrah}

Some jarrah trees die on all sites, irrespective of whether or not they are infested with $P$. cinnamomi. Aerial photography shows that that between 1978 and 1983 the mortality rate of jarrah on uninfested sites was 8.65 trees $1,000 \mathrm{ha}^{-1}$ in the previous 6 months, with about $20 \%$ of all deaths being in groups. On infested sites the deaths were of similar crown diameter, there was a similar proportion in groups, the only difference was in the rate, which was three times higher (24.62 trees $1,000 \mathrm{ha}^{-1}$ in the previous 6 months) [Supplementary data 2]. Investigations of isolated jarrah deaths between 1980 and 1984 showed that there were large spreading lesions in the inner bark at the root collar. The common eucalypt canker pathogens such as Cytospora, Endothia and Botryosphaeria (Davison and Tay 1983) were readily isolated from these lesions from trees on uninfested sites, and these pathogens, together with $P$. cinnamomi, were isolated from these lesions on jarrah trees on infested sites (Davison and Tay, unpublished data). Thus these isolated deaths appear to be similar on both infested and uninfested sites.

It was groups of dying jarrah trees that caused the greatest concern to foresters during the wet decades from the mid1940 s to mid-1960s. Deaths from waterlogging damage should have occurred on sites throughout the northern jarrah forest, not just on infested sites. Before 1965 there is insufficient information to determine whether sites where such deaths occurred were infested with $P$. cinnamomi, although the frequent mention that $B$. grandis died before jarrah (Hamilton 1951, Wallace and Hatch 1953), indicates that many of the sites would have been infested. However, as mentioned above, Podger (1968) reported one site where jarrah trees had died without the associated death of B. grandis, and the aerial photography shows that the proportion of jarrah trees in groups that die on uninfested and infested sites is similar [Supplementary data 2]. Investigations of groups of jarrah trees that died on uninfested sites in 1983, following exceptionally heavy rainfall in January 1982 and February 1983 [Supplementary data 1] indicated that tylosed sapwood, indicating waterlogging damage, occurred in their roots (Davison and Tay, unpublished data).

The conclusion drawn is that the only difference between infested and uninfested sites in terms of jarrah mortality is its rate. Pathogens, other than $P$. cinnamomi isolated from recently dead trees are similar. However jarrah deaths that occur on uninfested sites have received very little attention.

Pathology of native plants

The pathology of long lived native plants is very different from the pathology of agricultural crops, and needs to consider long term changes to both site and climate in addition to pathogens. Plants establish on sites that are not necessarily ideal for growth and reproduction (Janzen 1986) and they may establish during times which become less suitable as a result of climatic fluctuation (Cullen and Grierson 2009). Man's activities will also impact on the vegetation through road building, logging or mining, because changes that affect stand density, may make sites less suitable for long lived plants that are already established.

As you can see, the area of the pathology of native plants in natural ecosystems provides many opportunities for imaginative exploration, as has been recently demonstrated by Crone et al. 2012, 2013. A detailed knowledge of the host and its vulnerabilities is essential for making a diagnosis, and devising robust options for management.

Acknowledgments I thank D. M. Griffin for drawing my attention to the low recovery of Phytophthora cinnamomi from jarrah, J. H. Warcup for helpful discussions, F. C. S. Tay for his input into these investigations over many years, D. Fraser for assessing the aerial photography, B. Stewart for preparing Fig. 4, and F. Batini and F. J. Bradshaw for sharpening up my thoughts,. Most of this work was done whilst I was an employee of the Western Australian Departments of Conservation and Environment and Conservation and Land Management.

\section{References}

Abbott I, Loneragan O (1986) Ecology of jarrah (Eucalyptus margin$a t a)$ in the northern jarrah forest of Western Australia. Bulletin of the Department of Conservation and Land Management, No. 1. Perth, Western Australia

Batini FE (1973) Jarrah dieback - A disease of the jarrah forest of Western Australia. Bulletin 84, Forests Department of Western Australia. Perth

Batini FE, Hopkins ER (1972) Phytophthora cinnamomi Rands - A root pathogen of the jarrah forest. Aust For 36:57-68

Brandis AJ (1983) Introduction to the detection and interpretation of the symptoms of jarrah dieback disease in Western Australia. Technical Paper No. 3, Forests Department of Western Australia. Perth

Cahill DM, Rookes JE, Wilson BA, Gibson L, McDougall KL (2008) Phytophthora cinnamomi and Australia's biodiversity: impacts, predictions and progress towards control. Aust J Bot 56:279-310

Campbell WA (1949) Relative abundance of Phytophthora cinnamomi in the root zones of healthy and littleleaf-diseased shortleaf pine. Phytopathology 39:752-753

Carbon BA, Bartle GA, Murray AM (1981) Patterns of water stress and transpiration in jarrah (Eucalyptus marginata Don ex Sm.) forests. Aust For Res 11:191-200 
Christensen P (1975) Jarrah dieback - Soil temperature and moisture regimes of some southern forest types. Bulletin 88, Forests Department of Western Australia. Perth

Christensen-Dalsgaard KK, Fournier M, Ennos AR, Barford AS (2007a) Changes in vessel anatomy in response to mechanical loading in six species of tropical trees. New Phytol 176:610-622

Christensen-Dalsgaard KK, Ennos AR, Fournier M (2007b) Changes in hydraulic conductivity, mechanical properties, and density reflecting the fall in strain along the lateral roots of two species of tropical trees. J Exp Bot 58:4095-4105

Crombie DS, Tippett JT (1990) A comparison of water relations, visual symptoms, and changes in stem girth for evaluating impact of Phytophthora cinnamomi dieback on Eucalyptus marginata. Can J For Res 20:233-240

Crombie DS, Tippett JT, Hill TC (1988) Dawn water potential and root depth of trees and understorey species in south-western Australia. Aust J Bot 36:621-631

Crone M, McComb JA, O’Brien PA, Hardy GESTJ (2012) Annual and herbaceous perennial native Australian plant species are symptomless hosts of Phytophthora cinnamomi in the Eucalyptus marginata (jarrah) forest of Western Australia. Plant Pathol. doi:10.1111/ppa.12016

Crone M, McComb JA, O’Brien PA, Hardy GESTJ (2013) Assessment of Australian native annual/herbaceous perennial plant species as asymptomatic of symptomatic hosts of Phytophthora cinnamomi under controlled conditions. For Path 43:245-251

Cullen LE, Grierson PF (2009) Multi-decadal scale variability in autumn-winter rainfall in south-western Australia since $1655 \mathrm{AD}$ as reconstructed from tree rings of Callitris columellaris. Clim Dyn 33:433-444

Davison EM (1997) Are jarrah (Eucalyptus marginata) trees killed by Phytophthora cinnamomi or waterlogging? Aust For 60:116-124

Davison EM (2011) How do Phytophthora de Bary species kill trees? NZ J For Sci 41S:S25-S37

Davison EM, Speijers EJ, Tay FCS (2014) Comparison of sapwood invasion by three Phytophthora spp. Australas Plant Pathol. doi:10.1007/s13313-014-0287-6

Davison EM, Stukely MJC, Crane CE, Tay FCS (1994) Invasion of phloem and xylem of woody stems and roots of Eucalyptus marginata and Pinus radiata by Phytophthora cinnamomi. Phytopathology 84:335-340

Davison EM, Tay FCS (1983) Twig, branch and upper trunk cankers of Eucalyptus marginata. Plant Dis 67:1285-1287

Davison EM, Tay FCS (1985) The effect of waterlogging on seedlings of Eucalyptus marginata. New Phytol 101:743-753

Davison EM, Tay FCS (1988) Annual increment of Eucalyptus marginata trees on sites infested with Phytophthora cinnamomi. Aust J Bot 36:101-106

Davison EM, Tay FCS (1989) Phenology of Eucalyptus marginata on sites infested with Phytophthora cinnamomi. Aust J Bot 37:193206

Davison EM, Tay FCS (1995a) Predictions of where minimul damage to jarrah roots could result in tree death. New Phytol 131:393-401

Davison EM, Tay FCS (1995b) Damage to surface roots of Eucalyptus marginata trees at sites infested with Phytophthora cinnamomi. Aust J Bot 43:527-536

Dell B, Bartle JR, Tacey WH (1983) Root occupation and root channels of jarrah forest subsoils. Aust J Bot 31:615-627

Dell B, Wallace IM (1981) Recovery of Phytophthora cinnamomi from naturally infected jarrah roots. Australas Plant Pathol 10:1-2

Department of Conservation and Land Management (2003) Phytophthora cinnamomi and disease caused by it. Volume $1-$ Management Guidelines. Department of Parks and Wildlife, Perth

Dodd J, Heddle EM, Pate JS, Dixon KW (1984) Rooting patterns of sandplain plants. In: Kwongan, plant life of the sandplain, Eds. JS Pate \& JS Beard, 146-177, UWA Press
Doley D (1967) Water relations of Eucalyptus marginata Sm. under natural conditions. J Ecol 55:597-614

Erwin DC, Ribeiro OK (1996) Phytophthora diseases worldwide. APS Press, St. Paul, Minnesota

Farrington P, Turner JV, Gailitis V (1996) Tracing water uptake by jarrah (Eucalyptus marginata) trees using natural abundance of deuterium. Trees 11:9-15

Fordyce IR, Gilkes RJ, Loneragan WA, Beale S, Middleton N (2007) Vegetation zoning in relation to site and soil properties: a case study in the Darling Range, south-western Australia. J Roy Soc WA 90:1-14

Hamilton CD (1951) The dying of jarrah (E. marginata) in Western Australian forests. Progress of work done to July 1948. Unpublished manuscript available for viewing in the Department of Parks and Wildlife Library, Perth

Harding JH (1949) Pathogenic aspects of die back in the jarrah forest of Western Australia. Australian Forestry Conference. Pages from Forest Department file 391/49. Unpublished manuscript available for viewing in the Department of Parks and Wildlife Library, Perth

Hardy GESTJ, Colquhoun IJ Nielsen P (1996) The early development of disease caused by Phytophthora cinnamomi in Eucalyptus marginata and Eucalyptus calophylla growing in rehabilitated bauxite mined areas. Plant Pathol 45:944-954

Havel JJ (1979) Identification of vulnerable communities and prediction of disease spread. In: Phytophthora and Forest Management in Australia (ed. Old KM) CSIRO Canberra pp 64-72

Hüberli D, Tommerup IC, Colquhoun IJ, Hardy GESTJ (2002) Evaluation of resistance to Phytophthora cinnamomi in seedgrown trees and clonal lines of Eucalyptus marginata inoculated in lateral branches and roots. Plant Pathol 51:435-442

Janzen D (1986) Lost plants. Oikos 46:129-131

Kimber PC (1974) The root system of jarrah (Eucalyptus marginata). Research Paper No. 10. Forests Department of Western Australia. Perth, Western Australia

Liming FG (1957) Home made dendrometers. J For 55:575-577

Loneragan OW (1961) Jarrah (Eucalyptus marginata Sm.) and karri (Eucalyptus diversicolor F.v.M.) regeneration in southwest Western Australia. M.Sc. Thesis, University of Western Australia

McElrone AJ, Pockman WT, Martínez-Vilata J, Jackson RB (2004) Variation in xylem structure and function in stems and roots of trees to $20 \mathrm{~m}$ depth. New Phytol 163:507-517

Newhook FJ (1959) The association of Phytophthora spp. with mortality of Pinus radiata and other conifers. I. Symptoms and epidemiology in shelterbelts. N Z J Agric Res 2:808-843

Pate JS, Jeschke WD, Aylward MA (1995) Hydraulic architecture and xylem structure of the dimorphic root system of South-West Australian species of Proteaceae. J Exp Bot 46:907-915

Podger FD (1967) Research Project W.A.4 - The cause of jarrah dieback. Progress Report Number 3 - Waterlogging as a possible cause. Forest Research Institute, Western Regional Station, Kelmscott, WA. Unpublished manuscript available for viewing in the Department of Parks and Wildlife Library, Perth

Podger FD (1968) Aetiology of jarrah dieback. A disease of the dry sclerophyll Eucalyptus marginata Sm. forests in Western Australia. M.Sc. Thesis, University of Melbourne

Podger FD (1972) Phytophthora cinnamomi, a cause of lethal disease in indigenous plant communities in Western Australia. Phytopathology 62:972-981

Podger FD, Batini FE (1971) Susceptibility to Phytophthora cinnamomi root-rot of thirty six species of Eucalyptus. Aust For Res 5:9-20

Podger FD, Doepel RF, Zentmyer GA (1965) Association of Phytophthora cinnamomi with a disease of Eucalyptus marginata forest in Western Australia. Plant Dis Reporter 49:943-947

Poot P, Veneklaas E (2013) Species distribution and crown decline are associated with contrasting water relations in four common 
sympatric eucalypt species in southwestern Australia. Plant Soil 364:409-423

Shea SR (1975) Environmental factors of the northern jarrah forest in relation to pathogenicity and survival of Phytophthora cinnamomi. Bulletin 85, Forests Department of Western Australia. Perth

Shea SR, Dell B (1981) Structure of the surface root system of Eucalyptus marginata $\mathrm{Sm}$. and its infection by Phytophthora cinnamomi Rands. Aust J Bot 29:49-58

Shea SR, Gillen KJ, Leppard WI (1980) Seasonal variation in population levels of Phytophthora cinnamomi Rands in soil in diseased, freely-drained Eucalyptus marginata $\mathrm{Sm}$ sites in the northern jarrah forest of south-western Australia. Protection Ecol 2:135156

Shea SR, Shearer B, Tippett JT (1982) Recovery of Phytophthora cinnamomi from vertical roots of jarrah (Eucalyptus marginata Sm). Australas Plant Pathol 11:25-28

Shearer BL, Crane CE, Fairman RG, Dunne CP (2009) Ecosystem dynamics altered by pathogen-mediated changes following invasion of Banksia woodland and Eucalyptus marginata forest biomes of south-western Australia by Phytophthora cinnamomi. Australas Plant Pathol 38:417-436

Shearer BL, Shea SR, Fairman RG (1981) Infection of the stem and large roots of Eucalyptus marginata by Phytophthora cinnamomi. Australas Plant Pathol 10:2-3

Shearer BL, Tippett JT (1989) Jarrah dieback: the dynamics and management of Phytophthora cinnamomi in the jarrah (Eucalyptus marginata) forest of south-western Australia. Perth, Western Australia: Department of Conservation and Land Management, Bulletin No. 3

Silberstein R, Held A, Hatton T, Viney N, Sivapalan M (2001) Energy balance of a natural jarrah (Eucalyptus marginata) forest in Western Australia: measurements during the spring and summer. Ag For Met 109:79-104

Smith BJ, Shearer BL, Sivasithamparam K (1997) Compartmentalization of Phytophthora cinnamomi in stems of highly susceptible Banksia brownii treated with phosphonate. Mycol Res 101:1101-1107

Stahl W, Greaves R (1959) Report on a trip to Dwellingup, Western Australia, from 7.9.59 to 20.9.59 to investigate die-back in jarrah. Unpublished manuscript available for viewing in the Department of Parks and Wildlife Library, Perth
Stoate TN, Helms AD (1938) Stocktaking in the jarrah bush. Unpublished manuscript available for viewing in the Department of Parks and Wildlife Library, Perth

Stokes A, Mattheck C (1996) Variation of wood strength in tree roots. J Exp Bot 4:693-699

Tippett JT, Hill TC (1984) Role of periderm in resistance of Eucalyptus marginata roots against Phytophthora cinnamomi. Eur J For Pathol 14:431-439

Tippett JT, Hill TC, Shearer BL (1985) Resistance of Eucalyptus spp. to invasion by Phytophthora cinnamomi. Aust J Bot 31:409-418

Tippett JT, Shea SR, Hill TC, Shearer BL (1983) Development of lesions caused by Phytophthora cinnamomi in the secondary phloem of Eucalyptus marginata. Aust J Bot 31:197-210

Tyree MT, Yang S (1990) Water-storage capacity of Thuja, Tsuga and Acer stems measured by dehydration isotherms. Planta 182:420 426

Wager VA (1942) Phytophthora cinnamomi and wet soil in relation to the dying-back of avocado trees. Hilgardia 14:519-531

Wallace WR (1969) Progress report on jarrah dieback research in Western Australia. Forests Department of Western Australia. Perth. Unpublished manuscript available for viewing in the Department of Parks and Wildlife Library, Perth

Wallace WR, Hatch AB (1953) Crown deterioration in the northern jarrah forests. Unpublished manuscript available for viewing in the Department of Parks and Wildlife Library, Perth

Waring HD (1950) Report on a brief investigation into the death of jarrah (Eucalyptus marginata) in the Dwellingup Division, Western Australia. Unpublished manuscript available for viewing in the Department of Parks and Wildlife Library, Perth

Zentmyer GA (1968) Report on jarrah dieback problem in Western Australia. Unpublished report to the Forests Department WA, May 1968, included as Appendix I in Wallace, 1969. Unpublished manuscript available for viewing in the Department of Parks and Wildlife Library, Perth

Zentmyer GA, Thorn WA (1967) Hosts of Phytophthora cinnamomi. California Avocado Society Yearbook 51:177-186

Zimmermann MH (1983) Xylem structure and the ascent of sap. Springer, Berlin

Zimmermann MH, Jeje AA (1981) Vessel-length distribution in stems of some American woody plants. Can J Bot 59:1882-1892 